\title{
Removal Risks in Swedish Friesian Dairy Cows According to Parity, Stage of Lactation, and Occurrence of Clinical Mastitis
}

\author{
By P. H. Bendlxen and D. B Astrand. \\ Department of Anımal Hygiene, Skara, and \\ Department of Statistics, Data Processing and Agricultural Extension, \\ Swedish Unıversity of Agricultural Sciences, Uppsala, Sweden.
}

\begin{abstract}
Bendixen P. H. and D. B. Åstrand: Removal risks in Swedish Friesian dairy cows according to parity, stage of lactation, and occurrence of clinical mastitis. Acta vet. scand. 1989, 30, 37-42. - The removal risk of Swedish Friesian dairy cows was analysed. The risk of removal increased with parity, and first parity cows were removed earlier in lactation than cows of higher parities. A positive report of clinical mastitis increased the risk of removal, both in the month of developing mastitis and during subsequent part of lactation. The consequences of different removal pattern for epidemiologic analyses of observational studies are discussed.
\end{abstract}

cattle; culling; udder disease; epıdemiology.

\section{Introduction}

The risk of culling of dairy cows may vary dependent on parity, disease status, and productive performance (Oltenacu et al. 1984). Westell et al. (1982) found that undesirable disposals increased with age, $O^{\prime}$ Bleness \& van Vleck (1962) attributed the culling in older cows to a relative increase in reproductive problems, mastitis and udder problem; but Martin et al. (1982) found clinical diseases and poor production to explain only a small proportion of culling in dairy cows. Allaire (1977) found that risk of culling increased with age irrespective of disease status, but Dohoo \& Martin (1984) found a peak risk in second and third lactation.

The number of cows being removed and the time of removal during lactation have implications in epidemiologic studies of diseases that are not restricted to the puerperium. Use of cumulative incidence as a measure of disease occurrence requires that all cows are observed during the entire risk period. Unequal removal risks may result in different numbers of observed cases, e. g. the numerator of the cumulative incidence. In addition, measures of association may be biased if loss probabilities are unequal in groups to be compared (Kleinbaum et al. 1981).

This paper presents the accumulated risk of removal of Swedish Friesian dairy cows during lactation, according to parity and status of clinical mastitis. Data consist of 21,266 calving records with a potential follow-up period of 12 months.

\section{Materials and methods}

Data on diseases and removals were collected during a 4 year period on approximately 950 farms per year. Herd selection was purposive in order to cover all 24 counties in Sweden as well as different management and housing systems.

Data were mailed once a month by the farmers on a survey form specially designed for 
the project. Only farms with 12 consecutive reports during a year were included in the study, as data from persons that did not fulfill this obligation were suspected to be incomplete. Less than $20 \%$ of the farms originally engaged in the project at the beginning of a year of observation did not comply. Only calvings taking place during a year in herds that participated for the subsequent year were included in this study to ensure a potential observation of 12 months. Only cows of Swedish Friesian dairy breed (SLB) were included in this study. The farmers were given the following definition as diagnostic criteria for mastitis: Cows presenting one, some or all of the following signs: Swelling, warmth, pain, redness or visible changes in the milk. Removals were defined as dead or sold for slaughter. Detailed description of data collection, storage, and validation can be found in Bendixen et al (1986).

\section{Data analysis}

The risk of removal was calculated as a cumulative incidence $(\mathrm{CI})$, separately for the mastitis-positive and mastitis-negative cow populations, e. g. for cows with or without a positive report of clinical mastitis during the lactation period. The monthly risk of removal was calculated for a period of 11 months after the month of calving, to avoid problems caused by subsequent calvings. CI was the number of cows being removed divided by the number of cows at risk of removal. The number of cows at risk of removal in the month of calving was equal to the number of calvings in the mastitis-negative or mastitis-positive cow populations, and in the subsequent months of lactation it was equal to the original number of calvings minus the number of previously removed cows. Accumulated risk of removal during lactation was calculated by combining sub- sequent monthly incidences using the formula of Elveback (1958).

The putative increase in removal risk caused by a positive report of mastitis was evaluated by two measures of association; the monthly relative risk $\left(R_{M}\right)$ and the total relative risk $\left(R R_{T}\right) . R_{M}$ was the ratio between the removal risk for mastitis-positive cows in the month of developing mastitis and the removal risk for mastitis-negative cows in the corresponding months of lactation. $R_{\mathrm{T}}$ was the ratio between the removal risk for mastitis-positive cows from the months after developing mastitis till the eleventh month of the lactation and the removal risk for mastitis-negative cows during the corresponding period of lactation. Because removals and occurrence of mastitis were both related to parity, $R_{T}$ and $R R_{M}$ were parity-adjusted by a modified MantelHaenszel procedure (Kleınbaum et à 1982). Statistical analyses of $R R_{M}$ and $R R_{T}$ were performed by comparison of two binomial proportions (Kleınbaum et al. 1982).

\section{Results}

The accumulated risk of removal increased with parity both in the mastitis-negative and in the mastitis-positive cow populations (Table 1).

Mastitis-negative first parity cows were removed earlier in lactation than mastitisnegative cows of higher parities. Thus half of the number of first parity cows being culled was removed by the fifth month of lactation, but only one third of the total number of culled third prity cows was removed at that stage.

The increase in removal risk caused by a positive report of clinical mastitis varied according to stage of lactation (Table 2). Cows developing mastitis in the second month after calving had more than 5 times higher risk of removal in this month than cows 
Table 1. Percentage accumulated risk of removal from the month of calving (0) to eleventh month of lactation in mastitis-negative and mastitis-positive cow populations.

\begin{tabular}{|c|c|c|c|c|c|c|c|c|}
\hline \multicolumn{9}{|c|}{ Mastitis-negative cow population } \\
\hline $\begin{array}{l}\text { Month } \\
\text { after } \\
\text { calving }\end{array}$ & $\begin{array}{r}1 \\
n= \\
6681\end{array}$ & $\begin{array}{r}2 \\
n= \\
4362\end{array}$ & $\begin{array}{r}3 \\
n= \\
2824\end{array}$ & $\begin{array}{r}4 \\
n= \\
1638\end{array}$ & $\begin{array}{r}5 \\
\mathrm{n}= \\
935\end{array}$ & $\begin{array}{r}6 \\
n= \\
505\end{array}$ & $\begin{array}{r}7 \\
n= \\
272\end{array}$ & $\begin{array}{c}+7 \\
\mathrm{n}= \\
217\end{array}$ \\
\hline 0 & 2.38 & 1.05 & 1.63 & 2.50 & 3.10 & 3.37 & 4.41 & 4.61 \\
\hline 1 & 4.01 & 1.95 & 1.63 & 4.21 & 4.60 & 6.93 & 5.88 & 8.29 \\
\hline 2 & 5.63 & 2.84 & 3.72 & 5.01 & 5.99 & 8.71 & 7.72 & 10.14 \\
\hline 3 & 7.41 & 3.83 & 4.60 & 6.59 & 6.52 & 9.50 & 8.46 & 11.06 \\
\hline 4 & 8.94 & 5.11 & 6.09 & 8.42 & 7.91 & 10.89 & 10.66 & 13.82 \\
\hline 5 & 10.87 & 7.04 & 7.97 & 10.62 & 9.73 & 13.86 & 13.60 & 18.89 \\
\hline 6 & 12.41 & 9.12 & 9.99 & 12.70 & 12.83 & 16.44 & 18.75 & 24.42 \\
\hline 7 & 13.83 & 11.62 & 12.68 & 15.63 & 16.58 & 19.21 & 24.26 & 31.34 \\
\hline 8 & 15.24 & 14.53 & 15.90 & 18.80 & 21.28 & 22.18 & 29.04 & 35.48 \\
\hline 9 & 16.55 & 16.53 & 18.34 & 22.10 & 25.03 & 25.94 & 32.35 & 38.71 \\
\hline 10 & 17.93 & 18.25 & 20.33 & 24.54 & 26.74 & 29.50 & 36.03 & 42.40 \\
\hline 11 & 19.22 & 19.97 & 22.63 & 26.74 & 29.09 & 31.29 & 37.13 & 45.16 \\
\hline
\end{tabular}

Mastitıs-positıve cow population

\begin{tabular}{lrrrrrrrr} 
& \multicolumn{10}{c}{ Party } \\
\cline { 2 - 9 } $\begin{array}{l}\text { Month } \\
\text { after } \\
\text { calving }\end{array}$ & $\begin{array}{r}1 \\
\mathrm{n}=\end{array}$ & $\begin{array}{r}\mathrm{n}= \\
939\end{array}$ & $\begin{array}{r}3 \\
\mathrm{n}=\end{array}$ & $\begin{array}{r}4 \\
\mathrm{n}=\end{array}$ & $\begin{array}{r}5 \\
\mathrm{n}=\end{array}$ & $\begin{array}{r}\mathrm{n}= \\
521\end{array}$ & $\begin{array}{r}7 \\
\mathrm{n}=\end{array}$ & $\begin{array}{r}+7 \\
\mathrm{n}=\end{array}$ \\
\hline 0 & 960 & 187 & 85 & 62 \\
1 & 2.91 & 1.70 & 2.52 & 2.50 & 4.64 & 4.81 & 5.88 & 6.45 \\
2 & 6.35 & 4.15 & 5.56 & 6.14 & 7.43 & 8.56 & 10.59 & 9.68 \\
3 & 8.44 & 5.75 & 7.68 & 8.64 & 9.29 & 9.63 & 12.94 & 9.68 \\
4 & 11.77 & 7.88 & 9.40 & 10.56 & 11.76 & 11.76 & 15.29 & 14.52 \\
5 & 14.06 & 11.18 & 11.52 & 13.05 & 14.55 & 14.44 & 20.00 & 16.13 \\
6 & 16.88 & 14.70 & 14.57 & 16.51 & 16.41 & 19.25 & 21.18 & 17.74 \\
7 & 20.42 & 17.78 & 17.75 & 20.15 & 19.81 & 22.50 & 25.88 & 20.97 \\
8 & 22.29 & 21.94 & 21.85 & 25.53 & 25.08 & 26.74 & 30.59 & 22.58 \\
9 & 24.90 & 24.28 & 25.56 & 28.98 & 29.41 & 29.41 & 32.94 & 32.26 \\
10 & 26.28 & 27.05 & 28.87 & 33.40 & 32.20 & 32.09 & 38.82 & 37.10 \\
11 & 28.65 & 29.07 & 30.46 & 35.12 & 36.53 & 36.90 & 44.71 & 41.94 \\
\hline & 30.83 & 32.06 & 32.72 & 38.96 & 40.56 & 40.64 & 48.24 & 45.16 \\
\hline
\end{tabular}

without mastitis $\left(R R_{M}=5.6\right)$. A positive report of mastitis in the seventh months of lavtation did not significantly change the risk of removal during this month $\left(\mathrm{RR}_{\mathrm{M}}=\right.$ 1.9), but cows developing mastitis in the eleventh month had 3 times higher risk of removal than mastitis-negative cows $\left(R R_{M}=\right.$ 3.0).
A significantly higher risk of removal during the remaining part of lactation is associated with a positive report of mastitis, as shown by the magnitude of $R R_{T}$. In the sixth and ninth month after calving, however, the increase in risk of removal during the remaining part of lactation was not significant. 
Table 2. Number of cows with a positive report of mastitis $\mathrm{N}_{M}$ and parity-adjusted increase in removal risk ( $R R_{M}$ and $\left.R R_{T}\right)$ according to stage of lactation. For calculation of $R R_{M}$ and $R R_{T}$, see Material and methods.

\begin{tabular}{lrll}
\hline $\begin{array}{l}\text { Stage of } \\
\text { lactation }\end{array}$ & $\mathrm{NM}_{\mathrm{M}}$ & $\mathrm{RR}_{\mathrm{M}}$ & $\mathrm{RRT}$ \\
\hline 0 & 1230 & $4.0(\mathrm{a})$ & $1.9(\mathrm{a})$ \\
1 & 516 & $5.6(\mathrm{a})$ & $1.8(\mathrm{a})$ \\
2 & 385 & $4.3(\mathrm{a})$ & $1.6(\mathrm{a})$ \\
3 & 333 & $3.9(\mathrm{a})$ & $1.6(\mathrm{a})$ \\
4 & 229 & $3.0(\mathrm{a})$ & $1.6(\mathrm{a})$ \\
5 & 207 & $2.4(\mathrm{a})$ & $1.7(\mathrm{a})$ \\
6 & 156 & $2.1(\mathrm{c})$ & 1.4 n.s. \\
7 & 129 & 1.9 n.s. & 1.2 n.s. \\
8 & 127 & $3.3(\mathrm{a})$ & $2.3(\mathrm{a})$ \\
9 & 128 & $3.4(\mathrm{a})$ & 1.4 n.s. \\
10 & 129 & $2.2(\mathrm{c})$ & 2.1 (b) \\
11 & 263 & $3.0(\mathrm{a})$ & \\
\hline
\end{tabular}

$\mathrm{a}=\mathrm{p}<0.001 ; \mathrm{b}=\mathrm{p}<0.01 ; \mathrm{c}=\mathrm{p}<0.05$; n.s. $=$ non-significant.

\section{Discussion}

The observation of increased removal risk with increasing parity is at variance with the observation of Dohoo \& Martın (1984), who found a peak rate of removal for cows between 3.0-3.9 years or older than 7.0 years. However, not all of the 2008 cows commencing lactation in the study were followed to removal or recalving. Gröhn et al. (1986) in the study of 73,368 lactation records of Finnish Ayrshire cattle also found increased risk of removal after second parity.

The observation of increased risk of removal of mastitis-negative cows in higher parities does not support the hypothesis of mastitis being a major reason for removals in older cows (O'Bleness \& Van Vleck 1962). The increased removal risk during early stage of lactation in mastitis-negative cows of first parity could be due to low production and reproductive problems as suggested by Oltenacu et al. (1984).
The quantitative difference in removal risks between parities has consequences for calculations of cumulative incidences of diseases occurring during lactation. Martın et al. (1987) determine the "effective" denominator by subtracting one half of the number of withdrawals from the initial number at risk. The assumption is that mean withdrawal time occur at the midpoint of the follow-up period. However, when disease occurrence is concentrated to the first part of lactation (Dohoo et al. 1983) subtracting half of the number of withdrawals will systematically overestimate the cumulative incidence in higher parities, in which mean withdrawal time, according to Table 1, occurs during later part of lactation.

The data consisted of animal owner reported cases of clinical mastitis in order to reduce bias due to misclassification of disease status. Restriction of cases to those diagnosed and treated by veterinarians may result in misclassification of acute clinical cases as healthy subjects, when the cows are dying or being removed without consulting the veterinarians.

Increased risk of culling of mastitis-positive cows has been described previously (CoboAlbreu et al. 1979, Erb et al. 1985, Dohoo \& Martın 1984, Gröhn et al. 1986, Bendixen et al. 1988) but the change in risk at different stages of lactation is a new finding. No simple measure exists to demonstrate the influence of clinical mastitis on the rate of removal. The present analysis attempts to identify periods of higher risk of removal by comparison with removal risks of "diseasefree" animals during corresponding stages of lactation. Whether the prolonged risk of removal subsequent to a positive report of clinical mastitis is due to recurrence of clinical disease, decreased production or other sequelae remains to be elucidated. Unequal loss to follow-up may cause selec- 
tion bias in the measure of association (Kleınbaum et al. 1981). This validity problem has recieved less attention in veterinary epidemiology than confounding. Thus, studies to determine relationships between clinical mastitis and other diseases may suffer from selection bias due to the higher removal risk of mastitis-positive cows. Whereas confounding can be delt with at the planning stage or at the analytical stage of an observational study, only complete followup for all individuals during the risk period of disease can prevent selection bias. In view of the high removal risks of dairy cows during lactation this condition is difficult to satisfy.

\section{References}

Allaire FR, Sterwerf HE, Ludwick TM Vanations in removal reasons and culling rates with age for dairy females. J. Dairy Sci. 1977, 60, 254-267.

Bendlxen PH, Vllson B, Ekesbo I, Astrand DB Disease frequencies of tied zero-grazing dairy cows and of dairy cows on pasture during summer and tied during winter. Prev. Vet. Med. 1986, 4, 291-306.

Bendixen PH, Vilson B, Ekesbo I, Åstrand DB Disease frequencies in dairy cows in Sweden. V. Mastitis. Prev. Vet. Med. 1988, 5, 263-274.

Cobo-Abreau R, Martın SW, Stone JB, Willoughby $R A$ The rates and patterns of survivershıp and disease in a university dairy herd. Can. Vet. J. 1979, 20, 177-183.

Dohoo IR, Martın $S W \cdot$ Disease, production and culling in Holstein-Friesian cows V. Surv1vorship. Prev. Vet. Med. 1984, 2, 771-784.

Dohoo IR, Martın SW, Meek AH, Sandals WCD Disease, production and culling in HolsteınFriesian cows I. The data. Prev. Vet. Med. 1983, 1, 321-334.

Elveback $L$. Estımation of survivorship in chronic disease: The "actuarial" method. J. A. Stat. Assoc. 1958, 53, 420-440.
Erb HN, Smith RD, Oltenacu PA, Guard CL, Hillman RB, Powers PA, Smith MC, White $M E$ Path model of reproductive disorders and performance, milk fever, mastitıs, milk yield and cullıng in Holstein cows. J. Dairy Sc1. 1985, 68, 3337-3349.

Gröhn Y, Salonıemı H, Syvajärvı J An epıdemiological and genetic study on registered disease in Finnısh Ayrshıre cattle. I. The data, disease occurrence and culling. Acta vet. scand. 1986, 27, 182-195.

Kleınbaum DG, Morgenstern H, Kupper $L L$ Selection bias in epıdemıologic studies. Am. J. Epidemiol. 1981, 113, 452-463.

Kleinbaum DG, Kupper LL, Morgenstern $H$ Epidemiologic Research. Principles and Quantitative Methods. Lifetıme Learnıng Publications 1982, Belmont, CA, p. 345.

Martın SW, Azız SA, Sandels WCD, Curtıs RA The association between clinical disease, production and culling of Holstein-Friesıan cows. Can. J. Anım. Sc1. 1982, 62, 633-640.

Martın SW, Meek AH, Willeberg $P$ Veterinary Epidemiology. Principles and methods. Iowa State University Press, Ames, 1987, pp. 50-51.

$O$ 'Bleness $G V$, Van Vleck $L D$ Reasons for disposal of darry cows from New York herds. J. Dairy Sc1. 1962, 45, 1087-1093.

Oltenacu PA, Britt JH, Braun RK, Mellenberger $R W$ Effect of health status on culling and reproductive performance of Holstein cows. J. Dairy Sci. 1984, 76, 1783-1792.

Westell RA, Burnside EB, Schaeffer LR Evaluation of Canadian Holstein-Friesian Sires on disposal reasons of their daughters. J. Dairy Sc1. 1982, 65, 2366-2372.

Sammanfattning
Utslagnıngsrısk för svensk låglandsboskap ı
relatıon tıll kalvnıngsnummer, laktatıonsstadıum
och förekomst av klınısk mastıt
Utslagningsrisken för Svensk Låglandsboskap ana-
lyserades. Utslagningsrisken ökade med kalvnings-
nummer och förstakalvare blev utslagna tıdigare
under laktationen än kor 1 högre kalvnıngsnum-
mer. Klınisk mastı ökade utslagningsrisken både 1 
månaden för utveckling av mastit och under den . ningsfrekvenser påverkar resultatet av en epıdekvarvarande del av laktationen. Hur olika utslag- miologisk analys diskuteras.

\section{(Accepted June 8, 1988)}

Reprints may be requested from: P. H. Bendixen, Department of Animal Hygiene, Swedish Unıversity of Agricultural Sciences, Faculty of Veterinary Medicine, S-532 24 Skara, Sweden. 